Creative commons User License: CC BY-NC-ND

Abstracted by: EBSCOhost, Electronic Journals Service (EJS),

Google Scholar, Directory of Open Access Journals (DOAJ),

Journal Seek, Scientific Commons,

Food and Agricultural Organization (FAO), CABI and Scopus
Journal of Agricultural Extension

Vol. 21 (3) October, 2017

ISSN(e): 24086851; ISSN(Print); 1119944X

http://journal.aesonnigeria.org

http://www.ajol.info/index.php/jae

Email: editorinchief@aesonnigeria.org

\title{
Improving Rural Women Income through Cocoyam Value Addition Technologies in Abia State Nigeria
}

https://dx.doi.org/10.4314/jae.v21i3.11

\section{Onuekwusi G. C}

Department of Rural Sociology and Extension

Michael Okpara University of Agriculture University Umudike.

Email: gideonuekwusi@gmail.com; Phone:+2348037753165

\section{Odoemelam L. E}

Department of Rural Sociology and Extension

Michael Okpara University of Agriculture Umudike

Email: lovinaodoemelam@gmail.com; Phone:+2348034479348

\section{Kanu R. I}

National Root Crop Research Institute Umudike

Email: rose4@gmail.com; Phone:+2348024409863

\section{Abstract}

The study investigated how training and extension of technologies by the National Root Crops Research Institution (NRCRI) Umudike has empowered rural women to become entrepreneurs at various levels. Structured questionnaire was administered to 120 farmers in 2 agricultural zones of Abia (Ohafia and Umuahia). Data collected were analysed using linear regression model and t-test was used to test the hypothesis. The result revealed that the majority of the respondents were married (88\%) while $12 \%$ were single and were reasonably aware of the technologies. However, on the utilization of the technologies, out of the 5 processing technologies, only 3 had high level of utilization, processing of cocoyam into cake ( $\bar{x}=3.7)$ Bread ( $\bar{x} 3.5$ and Chin-chin $(\bar{x}=3.2)$. Also, a tangible impact was made in the livelihood of the respondents as there was a reasonable difference in income of the respondents after the training. The major challenges associated with the utilization were no extension agents to answer their questions $(\bar{x}=3.90)$ lack of commitment $=(\bar{x}=3.25$ and marketing of product $=$ $(\bar{x}=3.17)$ among others. It was therefore recommended that re-training and provision of market facilities should be intensified to enhance the utilization of the processing technologies and their impact among the respondents.

Key words: Processing technologies, value addition and training 
Creative commons User License: CC BY-NC-ND

Abstracted by: EBSCOhost, Electronic Journals Service (EJS),

Google Scholar, Directory of Open Access Journals (DOAJ),

Journal Seek, Scientific Commons,

Food and Agricultural Organization (FAO), CABI and Scopus
Journal of Agricultural Extension

Vol. 21 (3) October, 2017

ISSN(e): 24086851; ISSN(Print); 1119944X

http://journal.aesonnigeria.org

http://www.ajol.info/index.php/jae

Email: editorinchief@aesonnigeria.org

\section{Introduction}

Value added agriculture has attracted considerable attention in recent years as a means to increase and stabilize farm incomes and to rejuvenate primary agriculture and the rural economy. Value addition in agriculture simply means the act of adding value to product with a view to improve an existing product (FAO, 2011). Value addition is a change in the physical state or form of the product such as milling wheat into flour or making strawberries into jam that enhances its value, which should have unique attribution that goes beyond what is generally found in the conventional market. Value addition in agriculture predominately offers farmers the opportunity to receive a bigger share of the consumer's food money.

In Nigeria, value addition has come to the forefront of agricultural policy to strengthen small farm and farmers to survive in an era of agricultural liberalization, privatization and globalization. This can be attributed that agriculture in Nigeria is in the hands of rural poor farmers operating at subsistence level. As Marsan (2009) reported that value addition is a strategic area that offers an opportunity for shifting from subsistence agriculture to economic developments. Likewise, research studies have showed that value added agriculture can be one way to preserve small farmers and sustain farm operations.

Nigeria is the world's largest producers of cocoyam accounting for about $37 \%$ of the total world output Chukwu (2005). Cocoyam (Xanthosoma and Colocasia spp) is an important staple crop cultivated in the southern part of Nigeria (Ojiako et al 2007). It is variously grown by resource poor farmers, mostly women who intercrop cocoyam with yam, maize plantain among others (Ikwelle, Ezulike and Eze, 2003). However, cocoyam has suffered stiff competition from yam which is preferred for consumption and from cassava which yield more heavily and required less labour (Okoye, 2009). Agricultural produce is known to be highly perishable, hence most rural farmers do not get the required or desired reward for their work as most of their produce are lost a day or two after harvest. Based on this the National Root Crop Research Institute (NRCRI) Umudike which had the national mandate to research into root and tuber crops developed some processing technologies to reduce the perishability of the products and add value to these crops. The essence is to ensure that these crops can be put to wider uses in the home, for income generation and probably for export purposes.

National Root Crop Research Institute (NRCRI) Umudike, recently developed several cocoyam value added technologies aimed at addressing the high perishability of cocoyam tuber (corns and cormels). According to Aniedu (2012), these emerge as a result of rising demand for making cocoyam products available in more widely and readily useable forms. The development of a diverse value adding technologies for cocoyam is timely, appropriate and vital in the current effort to curb hunger, poverty and social conflict in Nigeria (Amamgbo, 2010).

In the traditional farming system women 'own' and plant cocoyam after the men have planted their yam, hence it is regarded as women's crop. As a result of male migration in search of white collar jobs, certain tasks that were traditionally performed by men are now left in the hands of women folk. That is gender based differentiation of farm tasks appear to be disappearing. Given the importance of 
Creative commons User License: CC BY-NC-ND

Abstracted by: EBSCOhost, Electronic Journals Service (EJS),

Google Scholar, Directory of Open Access Journals (DOAJ),

Journal Seek, Scientific Commons,

Food and Agricultural Organization (FAO), CABI and Scopus
Journal of Agricultural Extension

Vol. 21 (3) October, 2017

ISSN(e): 24086851; ISSN(Print); 1119944X

http://journal.aesonnigeria.org

http://www.ajol.info/index.php/iae

Email: editorinchief@aesonnigeria.org

cocoyam and the fact that its cultivation is proceeding, it becomes compelling to examine the processing and utilization of this crop. People regard cocoyam as poor man's food, and there was little or no processing of this crop to make it valuable; hence farmers earnings were not commensurate with the efforts they put in cocoyam production. In an effort to guide against poor earnings and encourage people to eat cocoyam, the Federal Government of Nigeria came up with Cocoyam Rebirth Programme (which year?). The purpose of which was to promote the new and improved forms of processing and utilization of cocoyam as well as empower the rural communities through training programmes, for sustainable food production, food security, income generation increased source of medicine for diabetic patients and possible foreign exchange earnings.

Aniedu (2012), indicated that such personal issues such as gender, availability of resources required for the use of innovation, priority and benefits expected to be gained motivate people to adopt innovations. This study is therefore aimed at investigating how the training programme of NRCRI has empowered the rural women.

The specific objectives were to:

1. examine the socio-economic characteristics of the respondents in the study area;

2. ascertain the level of utilization of the cocoyam value addition technologies extended to the rural women through training;

3. ascertain the effect of the technologies on the income of the respondents; and

4. identify challenges faced by the respondents during the training.

\section{Hypothesis}

There is no significant relationship between the training received by the respondents and their income after the training in the study area.

\section{Methodology}

The study area was Abia State. Abia State is made of 17 Local Government Areas and 3 agricultural zones. Agriculture is the major occupation of people in the State, employing about 60 to $70 \%$ of the inhabitants mainly women (source). The farm activities provide most of the time the household income, with family labour as major source of labour. The degree of involvement in farm activities especially cocoyam production is skewed in favour of the female folk (Agwu, 2004).

Multistage sampling procedure was used in the selection of the sample size. Out of the 3 agricultural zones in the State, 2 were purposively selected (Ohafia and Umuahia Zone) respectively. These zones were chosen because they have vast and fertile land for cocoyam production. From these zones, 2 Local Government Area were selected, followed by a selection of 3 Blocks from each LGA. This brought to a total of 12 blocks selected for the study. One cell was then selected from each block bringing to a total of 12 cells selected for the study. 10 rural women who were actively involved in cocoyam production were selected from each of the cells, bringing the total to 120 respondents. The rural women were subjected to 5 different 
Creative commons User License: CC BY-NC-ND

Abstracted by: EBSCOhost, Electronic Journals Service (EJS),

Google Scholar, Directory of Open Access Journals (DOAJ),

Journal Seek, Scientific Commons,

Food and Agricultural Organization (FAO), CABI and Scopus
Journal of Agricultural Extension

Vol. 21 (3) October, 2017

ISSN(e): 24086851; ISSN(Print); $1119944 X$

http://journal.aesonnigeria.org

http://www.ajol.info/index.php/jae

Email: editorinchief@aesonnigeria.org

value addition technologies training which lasted for 2 weeks in each agricultural zone; later (4 months) after the training, questionnaire was used to ascertain information on socio-economic characteristics and the level of adoption of each of the cocoyam value addition processing technologies exposed to the women. Data collected were analysed using descriptive and inferential statistics.

\section{Results and Discussion}

\section{Socio-Economic Characteristics of the Respondents}

The socio-economic characteristics of the respondents are shown on Table 1. The result reveals that the majority of the farmers were between the age range of 35-40 years have the greater percentage. This age group are known for their physical ability, productive and mental alertness in learning new technologies more than older farmers (Agwu, 2004). The implication of this finding shows that the women were strong being in their productive age (Olaniyi and Adewale, 2013). The table also reveal that about $88 \%$ of the respondents were married while only $12 \%$ were single. This implies that majority of the married women dominated the training programme and were to join the training. This must have been necessitated based on the need to gain more knowledge on value addition to enhance their income as well as diversifying the livelihood educational level augment family incomes in addition to their traditional roles in the family as mothers and care producers. The result further indicates that about $43 \%$ of the respondents had no formal education, $32 \%$ had primary education, $23 \%$ had secondary education and $20 \%$ had tertiary education. Educated farmers are expected to be more receptive to technologies, while farmers with low level of education or without education would be less receptive to improved farming, techniques or utilization of new technologies (Okoye, 2009). About 37\% of the respondents earned below $\$ 50,000-60,000$, per annum, $23 \%$ of the respondents earned $\$ 70,000$ and above, 21\% earned between $\$ 30,000-40,000$ while about $20 \%$ of the respondents earned between $\$ 10,000-20,000$ per annum. What is the implication? The mean farming experience of 13.5 years. With more experience, a farmer can become less averse to the risk implied by adopting a new technology (Nwaobiala,2014). The table also reveal that $42 \%$ of the respondents belong to cooperatives while $58 \%$ of the respondent did not belong to cooperative organizations. Belonging to cooperative societies will enhance participation in an intervention programme and Odoemenam (2007) opined that cooperative membership enhances access to information on improved technologies. 
Creative commons User License: CC BY-NC-ND

Abstracted by: EBSCOhost, Electronic Journals Service (EJS),

Google Scholar, Directory of Open Access Journals (DOAJ),

Journal Seek, Scientific Commons,

Food and Agricultural Organization (FAO), CABI and Scopus
Journal of Agricultural Extension

Vol. 21 (3) October, 2017

ISSN(e): 24086851; ISSN(Print); 1119944X

http://journal.aesonnigeria.org

http://www.ajol.info/index.php/jae

Email: editorinchief@aesonnigeria.org

Table 1: Socio-economic characteristics of the respondents

\begin{tabular}{lr}
\hline Variables & Percentag \\
\hline Age & \\
$25-30$ & 18.7 \\
$35-40$ & 25.0 \\
$45-50$ & 24.2 \\
$55-60$ & 18.7 \\
$65-70$ & 12.5 \\
& \\
Income N'000 & \\
$10,000-20,000$ & 20 \\
$30,000-40,000$ & 20.8 \\
$50,000-60,000$ & 36.7 \\
$70,000+$ & 22.5
\end{tabular}

Farming Experience

$5-10$

$15-20$

26.7

25-30

45.8

$35-40$

17.5

Marital Status

Married

87.5

Single

Member of Cooperatives

Belong to Cooperative

None

\section{Educational level}

Non- formal

Primary

Secondary

Others

\section{Source: Field Survey, 2015}

The implication of the result is that respondents that belong to cooperative societies may have more access to agriculture, information and production inputs (Onyenweaku and Nwaru, 2005). Acquisition of information about new technology demystifies it and make it more available to farmers (Banabana-Wabbi, 2002). Information enhances the uncertainty about technology performance hence may change individuals' assessment from purely subjective to objective over time, which will also facilitate training of the women on cocoyam value addition membership of an organization will brings them together, which following their resources, strengthening the human spirit and empowering them. 
Creative commons User License: CC BY-NC-ND

Abstracted by: EBSCOhost, Electronic Journals Service (EJS),

Google Scholar, Directory of Open Access Journals (DOAJ),

Journal Seek, Scientific Commons,

Food and Agricultural Organization (FAO), CABI and Scopus
Journal of Agricultural Extension

Vol. 21 (3) October, 2017

ISSN(e): 24086851; ISSN(Print); 1119944X

http://journal.aesonnigeria.org

http://www.ajol.info/index.php/jae

Email: editorinchief@aesonnigeria.org

Table 2: Level of utilization of cocoyam value addition technologies

\begin{tabular}{lcc}
\hline $\begin{array}{c}\text { Cocoyam Value added } \\
\text { Technologies }\end{array}$ & Utilization Score & Mean \\
\hline Biscuit & 366 & 3.05 \\
Chin-Chin & 388 & 3.2 \\
Cakes & 442 & 3.7 \\
Bread & 421 & 3.5 \\
Chips & 348 & 2.9 \\
\hline
\end{tabular}

Source: Field survey, 2015

\section{Level of Utilization of Cocoyam Value Addition Technologies}

The results in Table 2 show the level of utilization of cocoyam value addition technologies by the respondents in the study area. The result show that processing into cake has a mean score of $(\bar{x}=3.7)$, Bread $(\bar{x}=3.5)$, Chin-Chin $(\bar{x}=3.2)$, Biscuit $(\bar{x}=3.05)$ and Chips $(\bar{x}=2.9)$. Three out of the five technologies were above the total mean score of $\dot{X}=3.3$ ) therefore the remaining two were utilized less. The main reasons given by the women for high utilization of those technologies include, profitability, easy to handle, cultural acceptance and it is not labour intensive.

The result indicated that they understood the different aspect of value addition on cocoyam. It was found that respondents were not knowledgeable in biscuit and chips. The development will be beneficial for socio-economic development of the women. Overall respondents explicitly acknowledged NRCRI training was useful and enhance their knowledge.

\section{Effect of Training on Income of Respondents}

Table 3 shows the $\mathrm{R}^{2}$ value was 0.81 indicating that about $81.0 \%$ of the variations in the dependent variable were accounted for. The coefficient of income $\left(5.89^{\star}\right)$ was statistically significant. This result implies that a unit increase in the use of value added product of cocoyam technology will lead to a corresponding increase in the income of the respondents in the study area. This also implies that any increase in income will lead to increase in technology utilization among the farmers. Kehinde (2010), noted that the decision to adopt is often an investment decision. 
Creative commons User License: CC BY-NC-ND

Abstracted by: EBSCOhost, Electronic Journals Service (EJS),

Google Scholar, Directory of Open Access Journals (DOAJ),

Journal Seek, Scientific Commons,

Food and Agricultural Organization (FAO), CABI and Scopus
Journal of Agricultural Extension

Vol. 21 (3) October, 2017

ISSN(e): 24086851; ISSN(Print); 1119944X

http://journal.aesonnigeria.org

http://www.ajol.info/index.php/jae

Email: editorinchief@aesonnigeria.org

Table 3: Effect of the training on income of the respondents

\begin{tabular}{lccc}
\hline Variable & Estimates & Std Error & t-test \\
\hline Constant & 3976.563 & 7939.174 & 10.976 \\
Income & 0856 & 0.064 & $5.890^{*}$ \\
$\mathrm{R}^{2}$ & $0.81^{*}$ & & \\
$\mathrm{R}^{-2}$ (Adjusted) & 0.778 & & \\
F-ratio & 46.77 & &
\end{tabular}

* $\leq 0.05$. Source: Field Survey, 2015

Difference in Income of Respondents Before and After NRCRI training

Table 4 shows that the mean income of the respondents after training was N21,930.00 while before the training it was $\mathbf{N 9 . 0 7 3 . 6 7}$ with a paired mean of N12,856.33. This implies that the income of the respondents after the NRCRI capacity building training on value addition technologies were higher than their income before the training. Cocoyam duration after harvest or shelf life is low, based on this the National Root Crop Research Institute processing technology has not only empowered the women for sustainable livelihood but has made them entrepreneurs in various categories. Given that the variables were significant at $1 \%$ level of probability, it shows that there is a significant difference between their incomes before and after the training. It could be inferred that the intervention impacted positively on the incomes of the trainees. Therefore, we reject the null hypothesis which stated that there is no significant difference between the income of the respondents before and after training, and accept the alternatives.

Table 4: Difference in income of the respondents before and after NRCRI training

\begin{tabular}{|c|c|c|c|}
\hline Variables & Mean & Paired & z-value \\
\hline $\begin{array}{l}\text { Trainee's Income after } \\
\text { Intervention }\end{array}$ & $A 21,930.00$ & A12,856.33 & \\
\hline $\begin{array}{l}\text { Trainee's Income } \\
\text { before Intervention }\end{array}$ & 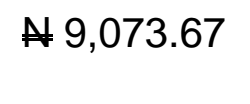 & & \\
\hline $\begin{array}{l}\text { Difference in income } \\
\text { after intervention }\end{array}$ & A12,856.33 & & 2.714 \\
\hline
\end{tabular}

\section{Challenges Faced by the Respondents During and After Training}

Table 5, shows the challenges faced by the respondents during and after training to include lack of training facilities had $(\bar{x}=3.25)$. To have an effective entrepreneurs training facilities and support must be easily available to the farmers. Effective arrangement need to be developed to regularly provide education and training at the right time, in the right place and with the right balance of technical knowledge and practical skills, marketing of products $(\bar{x}=3.17)$. 
Creative commons User License: CC BY-NC-ND

Abstracted by: EBSCOhost, Electronic Journals Service (EJS),

Google Scholar, Directory of Open Access Journals (DOAJ),

Journal Seek, Scientific Commons,

Food and Agricultural Organization (FAO), CABI and Scopus
Journal of Agricultural Extension

Vol. 21 (3) October, 2017

ISSN(e): 24086851; ISSN(Print); $1119944 X$

http://journal.aesonnigeria.org

http://www.ajol.info/index.php/jae

Email: editorinchief@aesonnigeria.org

Table 5: Challenges faced by the respondents training on utilization of value addition technology

\begin{tabular}{lc}
\hline Variables & Mean \\
\hline Lack of training facilities & 2.38 \\
Marketing of Products & 3.77 \\
Inadequate Knowledge & 2.63 \\
Lack of Transport Facilities & 2.90 \\
Inadequate Training Facilities & 2.62 \\
Lack of Commitment & 3.25 \\
Lack of Support Service and Trained & 3.90 \\
Extension & \\
\hline
\end{tabular}

\section{Source: Field survey, 2015}

The respondents realize that capturing value requires producing for buyers and final consumer. But just producing and selling is insufficient. This requires greater understanding and knowledge of value chain and their different elements. When they actively look for ways to capture the added value within the value chain, this will increase their products; inadequate knowledge $(\bar{x}=2.62)$. Daily pressures on the farm business requires farmers to make immediate decision based on knowledge acquired during the training. These decisions need to be made within a broader vision that guides the development of the bunnies' enterprise. The respondents must ensure that they are managing their enterprise with a long-term plan for the business so that it stays on course; lack of transport facilities $(\bar{x}=2.9)$; lack of commitment $(\bar{x}$ = 3.25) New technologies are needed in order to adapt to a changing economy and changing market. The respondents are not only consumers and users of these technologies but should also be active participants in designing testing, adapting and introducing them to the farming systems. Lack of support service $(\bar{x}=3.90)$. Farmers advancing through the five stages of the technologies will need information, advice and support. The support needs should cover all aspect of running a profitable market oriented enterprise. According to Aniedu (2012) for rural poor women to adopt or utilize technologies these challenges should be addressed. Otherwise any technology that will add more work to them will not be readily acceptable by the women. 
Creative commons User License: CC BY-NC-ND

Abstracted by: EBSCOhost, Electronic Journals Service (EJS),

Google Scholar, Directory of Open Access Journals (DOAJ),

Journal Seek, Scientific Commons,

Food and Agricultural Organization (FAO), CABI and Scopus
Journal of Agricultural Extension

Vol. 21 (3) October, 2017

ISSN(e): 24086851; ISSN(Print); 1119944X

http://journal.aesonnigeria.org

http://www.ajol.info/index.php/iae

Email: editorinchief@aesonnigeria.org

\section{Conclusion and Recommendation}

The study investigated how cocoyam value addition technologies adopted by rural women in Abia sited enhanced their income. From the results of the study, it revealed that income of the respondents after the NRCRI training on cocoyam value addition were higher than their income before the training, even though with some challenges (marketing of products among others). Therefore, the paper recommends that the respondents should be guided by the NRCRI, on how to source market for their products and equipment for proper utilization.

\section{References}

Agwu A.E. (2004) Factors Influencing Adoption of Improved Cowpea Production Technology in Nigeria. Journal of International Agriculture and Extension $11(1)$.

Amamgbo (2010) Training Manual on Root and Tuber Crops Value Additional National Root Crop Research Institute, Umudike.

Aniedu C., Aniedu, O.C. and Nwakor N. (2012) Impact and Adoption of Value Added Innovations in Root and Tuber Crops Among Farmers in Imo State, Nigeria. Global Journal of Science Frontier Research Agriculture and Veterinary Science Vol. 12(11).

Banabana-Wabbi, J. (2002) Assessing Factors affecting Adoption of Agricultural Technologies. The case of Integrated Pest Management in Kuni District Eastern Uganda. Unpublished M.Sc. Thesis Dept. of Agriculture and Applied Economics Virgina Polytechnic Institute and State University USA.

Chukwu, G. O (2015). Land use for Cocoyam in Nigeria. Implications for Cocoyam Rebirth. Global Journal of Agricultural Resource 5 (2) Pp 25 - 36

Food and Agricultural Organization (2011). Women in Agriculture, Choosing the gender gap for development. The State of Food and Agriculture, FAO, Rome, Italy

Ikwelle, M.C., Ezulike, T.O. and Eze, O.O.N. (2003). Contribution of Root and Tuber Crops to the Nigerian economy. Proceedings of the $8^{\text {th }}$ triennial symposium of the international society for tropical Root Crops. African Branch (ISTRC-AB) held at the IITA, Ibadan.

Kehinde, E.A. (2010) A Review of factors Affecting use of Agricultural extension services by small scale farmers in food production in Kwara State, Nigeria. Conference proceedings of the $18^{\text {th }}$ annual conference of agricultural extension society of Nigeria (AESON).

Marsan, C. D. (2009). Top 10 technology skill. Online) Available: http://www.networkworld.comHome/cduffy\%20marsan.html (January 30, 2016).

National Root Crop Research Institute N.R.C.R.I (2010) Annual Report. Not complete 
Creative commons User License: CC BY-NC-ND

Abstracted by: EBSCOhost, Electronic Journals Service (EJS),

Google Scholar, Directory of Open Access Journals (DOAJ),

Journal Seek, Scientific Commons,

Food and Agricultural Organization (FAO), CABI and Scopus

\author{
Journal of Agricultural Extension \\ Vol. 21 (3) October, 2017 \\ ISSN(e): 24086851; ISSN(Print); 1119944X \\ http://journal.aesonnigeria.org \\ http://www.ajol.info/index.php/jae \\ Email: editorinchief@aesonnigeria.org
}

Nwaobiala, C.U. (2014). Adoption of fish production technologies among homestead catfish farmers in Ebonyi State, South East, Nigeria. Journal of Applied Agricultural Research 6(2).

Odoemenam, I.U. (2007) Capital Resource Mobilization and Allocation Efficiency by Small Scale crop farmers of Benue State. Department of Agricultural Economics Managed and Extension, Ebonyi State University, Abakaliki, Nigeria

Ojiako. A., Asumugha, G.N., Ezedinma C. and Uzokiwe, N.E. (2007) Analysis of Production trends in the major root and tuber crops in Nigeria, 1961-2005. Resource in crops Vol. 8 (2).

Okoye, B.C. (2009) Adoption scale Analysis of Improved Cocoyam Production Processing and Storage Technologies across gender in Enugu North. Agricultural zone of Enugu State, Nigeria. Proceeding of the $43^{\text {rd }}$ Annual Conference of the Agricultural Society of Nigeria held at NUC Auditorium and RMRDC, Abuja.

Olaniyi, O.A. and Adewale, J. O. (2013) Women Farmers Perception on Utilization of Market Information on Cassava in Osun State, Nigeria. Journal of Agricultural Extension.

Onyenweaku, C.E. and J.C. Nwaru (2005) Application of Stochastic Frontier Production Function to the Measurement of Technical Efficiency in Food Production in Imo State, Nigeria. Nigeria Agricultural Journal. 